\title{
Laohavichien Model of Leadership And Quality For Pakistan. What It Is And Why It's Important For SME's.
}

\author{
Naveed Saif \\ The university of lakki Marwat \\ Muhammad Tahir Khan \\ Imperial collage of business studies. \\ Sadaqat Ali \\ UST BANNU \\ Fazli Wadood \\ University of BUNER $\mathrm{kp}$
}

\begin{abstract}
Objectives; Leadership become one of the most important topic among behavioral scientist and management researchers. The current research study try to investigate the relationship between transactional, transformational styles of leadership in paying way for Quality Management (QM) Practices in Khyber Pakhtoon Khwa SME's sector. For this purpose, data was collected from manufacturing sector through adapted version of questionnaires. In first stage CFA was conducted to remove item having lower loading. In the next stage through SEM analysis was performed. Results indicate that During CFA analysis most of the components of the adopted construct were removed due to poor fit model. As a result, the original concept of the adopted construct was renamed on the basis of retained factors. During SEM analysis the hypothetical relationship were partially supported, and results indicate that for the smooth functioning of manufacturing sector of SME's it is strongly recommended to adopt the modern techniques of QM practices that must be alien with international standards. However, in Pakistan cultural set up its results are quite different. And it's open new way of research in theory of Leadership.
\end{abstract}

Keywords: Transactional, Transformational, Leadership, SME's,

\footnotetext{
1. dr.naveed.saif@hotmail.com

2. dr.tahirkhanm@gmail.com,

3. alisadaqat2007@yahoo.com,

4.wadoodam@gmail.com
}

Page $\mid 43$ 
IBT Journal of Business Studies (IBT-JBS) Volume 15 Issue 2 December 2019

\section{INTRODUCTION}

In 2004, Pakistan expressed the significance of association between leadership and quality through its first national quality policy. Effects for the establishment of Pakistan National quality Award (PNQA) was started with the association of National productivity organization. In accordance with the rules and regulations of PNQA as well as TQM, the Pakistan quality and leadership shows great resemblance in accordance with the international leadership and quality model such as: (Malcolm Baldrige National Quality Award) MBNQA model of the US, (European foundation for Quality Management) EFQM model as well as Malaysian Quality Award (MQA). All these international quality Award specifies that leadership is a dominant factor to enhance quality performance as well as to conduct Quality Management practices (QMP). In first phase, TQM act as a model and a strategy in flexible dynamic global environment.

The research study interprets the association of transactional and transformational leadership as well as the linkages of quality practices and quality performance in the organization of Pakistan in order to determine that how quality practices and its management works upon, and how it can affect the quality of organizational performance. The structural equation model (SEM) was implemented for the data analysis purpose. PNQA has also been developed in Pakistani organization which assigns values to the association of leadership and quality interaction. PNQA also acts as benchmark and it has the same function as that of MBNQA model. PNQA model which has been deployed in Pakistani organization as well as MBNQA model which is working in American organization expresses that leadership is a critical factor for quality system performance and enhances quality management. Rehan, Adeel, \& khan,2016) suggested that different organization in all over the world is using the philosophy of QM. The concept of QM has a great significance for the Pakistani corporation as well (Steinbacher \& Steinbacher, 1993). Sousa \& Voss (2002) documented that QM does not work significance in all organizations everywhere in the world. Jain \& Tabak (2002) suggested that corporate support, Managerial understanding and Quality demands are variables which determine quality in organization and which in turn effect quality processes. Sousa \& Voss (2001) interpreted that there is association between physical context of an institution as well as Quality Management (QM). Sousa \& Voss (2001) evaluated that QM has depend upon the strategy of manufacturing institutions.

The existing researchers (Laohavichien, Fredendall \& Cantrell, 2011; Laohavichien, Fredendall \& Cantrell, 2009; Saif, 2015; Rehan, Adeel, \& khan,2016) evaluates the association of transactional and transformational leadership to find out infrastructure QM practices. Researchers have examined the concept of QM in developed countries (Laohavichien et al. 2009a, 2011b; Omar,2017). The current research process also try to specify the QM will brought the same consequences for the country like Pakistan or not. As the culture and economies varies from country to country, it means that QM which has favorable results will in one country cannot produce the same outcomes in another country. Waldman et al (1998) suggested that various research process have executed the association of leadership and QM. However, on the basis of several research process, leadership provides a context 
to QM in organization (Waldman et al, 1998). This research study provides a great insight of how leadership specifies significance of QM. This study also focuses on how previous cross-cultural researchers have documented the effect of leadership on quality.

\section{LITERATURE REVIEW}

\section{Leadership}

Different leadership model and theories e.g. Path-Goal Style of leadership designed by (House, 1971), Leader Member Relationship Model by (Danserea, Graen \& Haga., 1975)were developed by the researchers from time to time. Dean \& Bowen (1994) recommend that in order to measure the impact of leadership with QM practices, the best option are to investigate transformational and transactional adopted QM practices in their physical environment (Laohavichien et al., 2011; Saif,2015).

According to Dean \& Bown (1994) transformational leadership is a significant leadership style for organizational QM process. They do not focus on QM practices in institutions. Waldman (1994) researched that transformational leadership is dominant for QM processes rather than transactional leadership. Similar findings were reported by Laohavichien et al., (2011). The reason is that transactional leadership is a short-term phenomenon, streamline short-term organizational processes but intervene long-term organizational processes. On the other side, transformational leadership is a long-term phenomenon, streamline long-term institutional processes and leads to the long-term institutional prosperity.

In the view of Anderson et al (1995) visionary leadership is the basis for QM processes. He further analyzed that individual model: such as transactional or transformational leadership cannot perform well as a single model because it has lower impact on QM practices. In case of combination of both style of leadership (Transformational and Transactional) model have dominant effect on QM processes (Bass, 1985; Bass \& Avolio, 1990). Burns (1978) expressed that transformational leader motivates their followers in order to enhance performance at the higher job position. Bass (1985) suggested that transformational leaders motivates their followers for the overall group goals while sacrificing their own benefits and incentives. It will increase the intrinsic motivation of employees while executing organizational objectives (Bass \& Avolio, 1990). It has been interpreted that transactional leadership works in organization in accordance with the exchange of rewards. When employees contribute their efforts towards organizational processes then they must receive a reward in exchange of their efforts. Bass and Avolio (1997) suggested that some leaders in organization also exhibit mix behavior of transformational as well as transactional leadership.

Podsakoff et al (1996) analyzed and interpreted the transactional as well as transformational leadership behavior on the basis of well-defined criteria. By using the appropriate scale, Podsakoff analyzed the 6 dimensions of transformational leadership and two dimensions of transactional leadership. 
Podsakoff et al (1990) Model of leadership use by (Saif, 2015; Saif et al., 2016; Laohavichien et al., 2011a, 2009b) indicate that the dimension "To articulate a vision" described the leader ability how to clarify a vision. The second dimension "Provide an appropriate model" described that leaders must have the potential to influence their followers. By doing so, the leader can be able to "foster the acceptance of group goals". According to this dimension, the aim of leader is to increase collaboration among employees for the achievement of institutional goals. "High performance expectation" which is the fourth dimension described that leader must have the potential to show quality performance. The dimension of "providing individualized support" describes the leader potential to provide assistance and support to the individual employees for the conduct of organizational processes. The last dimension "intellectual stimulation" stresses that leaders enhances performances of their followers by giving proper attention.

Transactional leadership relies on two aspects (Saif., 2015; Saif et al., 2016; Laohavichien et al., 2011a;2009b). Contingent punishment" as well as "Contingent reward". According to the "Contingent reward" employees will be best treated and they will receive reward from their supervisors on behalf of their efficient efforts. The employees will perform their tasks in the best possible way to execute organizational goals and objectives. The "Contingent Punishment" stresses that if employees do not achieve their standards or tasks, then employees will be threatened and they will receive negative feedback from their supervisors Podsakoff et al (1990).

Anderson et al (1995) observed that the forerunning of QM as well as QM theoreticians (Dean and Dow, 1994) have contributed good effort, and worked for creative research literature on QM studies (Curkovic, Vickery \& Droge, 2000). According to Ahire (1996) leadership is a significant impact on QM practices in institutions (Saraph et al, 1989). Souse and Voss (2002) suggested that leadership is necessary for QM practices but it has not been confirmed what kind of leadership is significant for QM. Anderson et al (1995) stated that the construct related to measure the attributes of top management quite different from Transactional as well as transformational leadership. It has been evaluated that top management support is very important to interpret variances in quality practices (Rehan, Adeel and khan., 2016; Flynn, Schroeder and Sakakibara,, 1995).

\section{QM Practices}

Sousa \& Voss (2002) interpreted that for the first time QM practices was described as core practices of categorization by Flynn et al (1995). The work on QM practices was further developed and supported by (Ho, Duffy, \& Shih, 2001) as well as Rahman and Bullock (2002). Sousa and Voss (2002) also executed an association between infrastructure QM practices as well core QM practices. The study of (Sousa \& Voss, 2002) is an attempt to apply the management theory into the concept of QM practices in order to find out the association among QM processes and theoretically developed fields. The findings of the study conducted by Flynn et al (1995) showed favorable linkages between cores QM as well as infrastructure QM processes. It has been expressed that the role of core QM processes is like a mediator in the association among IQM practices as well as Quality performance (Rahman \& Bullock, 2002). However the work of Flynn et al (1995) expressed 
that there is no direct association between infrastructure QM processes as well as quality performance. Core QM practices is significant and have direct impact on quality performance (Flynn et al.,1995; Laohavichien et al.,2011).

Quality Management Concept

Waldman (1994) examined that how implementation of Quality Management in organization physical context can enhance organizational progress. They identified 3 important factors necessary for the progress of an institution. If these 3 Criterions are fulfilled then it will certainly results in favorable progress of an institution.

1. If capabilities of organizational employees is improved then it will increase efficiency of an institution,

2. Organization must ensure, what consumer requires. By producing quality product to fulfill customer products,

3. Satisfaction is an important factor. By increasing employee's satisfaction, employees will give favorable feedback towards organizational processes during the working hours. Beyond satisfaction, employee's knowledge about organizational products should be enhanced.

Sousa and Voss (2002) identified the following characteristics of quality management practices.

1. To describe the philosophy of Quality,

2. How Quality management practices can increase the efficiency of firm performance,

3. What is the significance of quality and how it can be applied to the theory of management?

Sousa and Voss (2002) developed a theoretical framework which shows how organization can enhance its performance with implementation of Quality Management practices. 


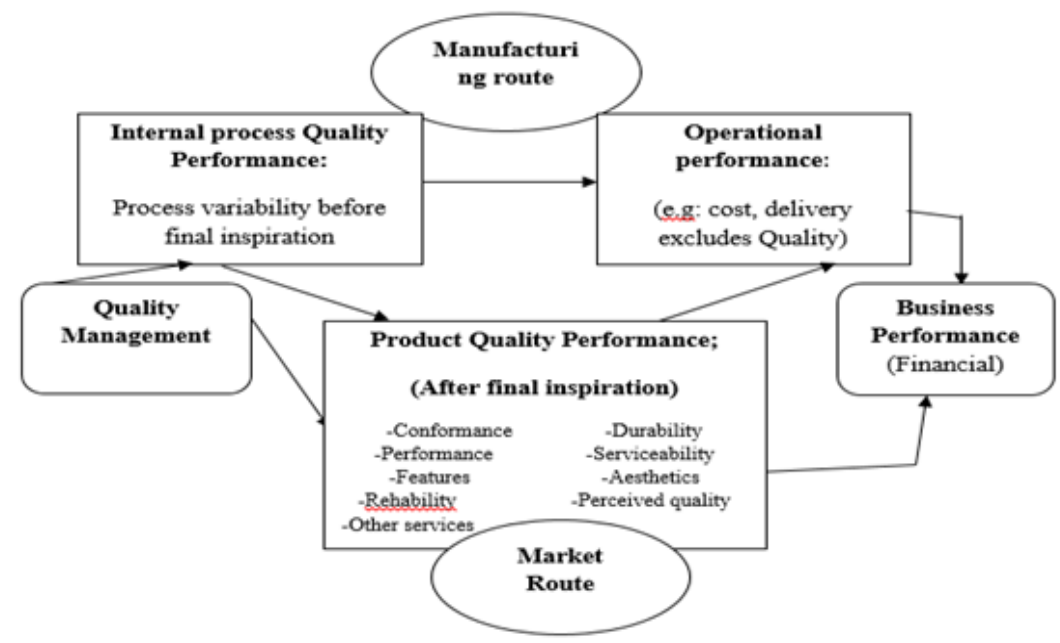

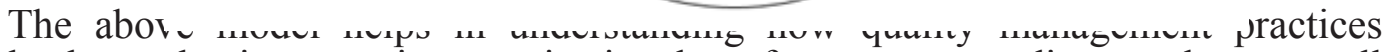
leads to the increase in organizational performance regarding market as well as manufacturing route. Internal processes, quality performance, operational performance represents manufacturing route of an organization. The manufacturing organization can enhance performance by take improvement in their internal processes and determining defects in the manufacturing processes. Thus by increase in operational performance can exhibit increase in institutional performance. Manufacturing route deals with how operational processes can be enhanced in order to reduce cost of production.

The effect of operational performance and product quality was tested on organizational performance. It was analyzed that product quality has significant effect on performance of organization as compared to operational performance. Quality management provide a strong base to product quality performance and operational performance for the significant impact on institutional performance.

Table 2.1. Different characteristics of Infrastructure and Core Quality Management Practices.

\begin{tabular}{|l|l|l|l|l|l|}
\hline $\begin{array}{l}\text { Infrastructure: } \\
(\mathrm{QM}) \text { Practices }\end{array}$ & $\begin{array}{l}\text { Management } \\
\text { Support }\end{array}$ & $\begin{array}{l}\text { Customer } \\
\text { Focus }\end{array}$ & $\begin{array}{l}\text { Human } \\
\text { Resource } \\
\text { Management }\end{array}$ & $\begin{array}{l}\text { Organization } \\
\text { Corporation }\end{array}$ & $\begin{array}{l}\text { Supplier } \\
\text { Management }\end{array}$ \\
\hline Core (QM) Practices & $\begin{array}{l}\text { Statistical } \\
\text { Process } \\
\text { Control }\end{array}$ & $\begin{array}{l}\text { Process } \\
\text { Management }\end{array}$ & $\begin{array}{l}\text { Design } \\
\text { Quality } \\
\text { Management }\end{array}$ & & \\
& & & \\
\hline
\end{tabular}

It has been expressed that the association between leadership style as well as quality management practices has also been studied in the physical environment of the country like USA and Thailand (Laohavichienet al.2011; Laohavichien et al.2009). The purpose of the research study was to execute how the associations of USA and Thailand have contributed towards Quality management practices. For the execution of the study, five component of infrastructure Quality management (MS, CF, HRM, OC, SM) as well as 3 component of core Quality management (SPC, PM, DQM) was adapted (Laohavichien et al.2011). 
Table 2.2. Infrastructure Quality Management Practices

\begin{tabular}{|l|l|l|l|l|l|l|l|l|l|l|l|}
\hline S.No & $\begin{array}{l}\text { Infrastructure } \\
\text { Quality } \\
\text { Management } \\
\text { Practices }\end{array}$ & C.F & O.C & H.R & S.M & Trai & W.A & Emp & QMP & T.M & O.O \\
\hline 1 & $\begin{array}{l}\text { SaraphBenson, } \\
\text { and Schroeder. } \\
(1989)\end{array}$ & $\mathrm{X}$ & $\mathrm{X}$ & $\mathrm{Y}$ & $\mathrm{X}$ & $\mathrm{Y}$ & $\mathrm{X}$ & $\mathrm{X}$ & $\mathrm{Y}$ & $\mathrm{Y}$ & $\mathrm{X}$ \\
\hline 2 & $\begin{array}{l}\text { Andreson et al. } \\
(1995)\end{array}$ & $\mathrm{X}$ & $\mathrm{Y}$ & $\mathrm{X}$ & $\mathrm{X}$ & $\mathrm{Y}$ & $\mathrm{X}$ & $\mathrm{Y}$ & $\mathrm{X}$ & $\mathrm{Y}$ & $\mathrm{X}$ \\
\hline 3 & Flynn (1995) & $\mathrm{Y}$ & $\mathrm{X}$ & $\mathrm{Y}$ & $\mathrm{Y}$ & $\mathrm{X}$ & $\mathrm{Y}$ & $\mathrm{X}$ & $\mathrm{Y}$ & $\mathrm{Y}$ & $\mathrm{X}$ \\
\hline 4 & Powell (1995) & $\mathrm{Y}$ & $\mathrm{X}$ & $\mathrm{X}$ & $\mathrm{Y}$ & $\mathrm{Y}$ & $\mathrm{X}$ & $\mathrm{Y}$ & $\mathrm{Y}$ & $\mathrm{Y}$ & $\mathrm{Y}$ \\
\hline 5 & $\begin{array}{l}\text { Aihere et al. } \\
(1996)\end{array}$ & $\mathrm{Y}$ & $\mathrm{X}$ & $\mathrm{Y}$ & $\mathrm{Y}$ & $\mathrm{Y}$ & $\mathrm{X}$ & $\mathrm{Y}$ & $\mathrm{X}$ & $\mathrm{Y}$ & $\mathrm{X}$ \\
\hline 6 & $\begin{array}{l}\text { Laohavichien et } \\
\text { al.(2011) }\end{array}$ & $\mathrm{Y}$ & $\mathrm{Y}$ & $\mathrm{X}$ & $\mathrm{Y}$ & $\mathrm{X}$ & $\mathrm{X}$ & & $\mathrm{X}$ & $\mathrm{Y}$ & $\mathrm{X}$ \\
\hline
\end{tabular}

Table 2.2 describe infrastructure Quality Management practices (The characteristics of Quality Management) and contain the variables like Organizational cooperation, Customer focus, Supplier management, Top management support as well as Work force.

The table 2.2 provides the complete information's of all those studies that have been conducted on attitude of leader, to implement infrastructure quality. Flynn (1995a) used the variable of customer support in the study of IQM. Customer support deals with, what is the customer perception toward QMP and how organizational management can improve satisfying behavior of customers (Powell, 1995; Aihere et al, 1996).

The table (2.2) also interprets (the association between organization, supplier's management and work force management). Supplier management represents the association between suppliers and organization. Work force management deals with skills, ability and achievements of organizational employees) based on the studies of (Flynn, 1995a; Powell, 1995; Aihere et al, 1996; Laohavichien et al.2011).

Anderson et al (1995) interpreted and analyzed employee training on the basis of (IQM) techniques. The purpose of training was to improve the skills of employees to compete with the face of uncertainty, problems and how to use the new standards when applied to the institution (Saraph et al, 1989; Powell, 1995; Aihere et al, 1996).

Page 49 
IBT Journal of Business Studies (IBT-JBS) Volume 15 Issue 2 December 2019

TABLE (2.3): MEASURING CORE QUALITY MANAGEMENT PRACTICES (CQMP):

\begin{tabular}{|l|l|l|l|l|l|l|l|l|l|l|}
\hline S.No & $\begin{array}{l}\text { Core QM } \\
\text { practices }\end{array}$ & P.M & S.P.C & D.Q.M & Bench & Q.D.R & P.D & Z.D & Q.D & F.M \\
\hline 1 & $\begin{array}{l}\text { Saraph et al. } \\
(1989)\end{array}$ & Y & X & Y & X & Y & Y & X & X & X \\
\hline 2 & $\begin{array}{l}\text { Andreson et al. } \\
(1995)\end{array}$ & Y & X & X & X & X & Y & X & Y & X \\
\hline 3 & Flynn (1995a) & Y & Y & X & X & X & Y & X & X & X \\
\hline 4 & Powell (1995) & Y & X & X & Y & X & X & Y & X & Y \\
\hline 5 & $\begin{array}{l}\text { Aihere et al. } \\
\text { (1996) }\end{array}$ & $\mathrm{X}$ & $\mathrm{Y}$ & $\mathrm{Y}$ & $\mathrm{Y}$ & $\mathrm{Y}$ & $\mathrm{X}$ & $\mathrm{X}$ & $\mathrm{X}$ & $\mathrm{X}$ \\
\hline 6 & $\begin{array}{l}\text { Laohavichien et } \\
\text { al.2011 }\end{array}$ & $\mathrm{Y}$ & $\mathrm{Y}$ & $\mathrm{Y}$ & $\mathrm{X}$ & $\mathrm{X}$ & $\mathrm{X}$ & $\mathrm{X}$ & $\mathrm{X}$ & $\mathrm{X}$ \\
\hline 7 & Saif (2015) & $\mathrm{Y}$ & $\mathrm{Y}$ & $\mathrm{Y}$ & $\mathrm{X}$ & $\mathrm{X}$ & $\mathrm{X}$ & $\mathrm{X}$ & $\mathrm{X}$ & $\mathrm{X}$ \\
\hline
\end{tabular}

$\mathrm{P} . \mathrm{M}=\mathrm{SPC}=; \mathrm{DQM}=$ Bench $=\mathrm{QDR}=\mathrm{PD}=\mathrm{ZD}=\mathrm{QD}=\mathrm{FM}=$

Table (2.3) gives the full explanation about all the variables of CQMP in order to study the Quality management practices. Process management, Design quality management, Benchmarking, product design, Zero defect, Statistical control process, Flexible manufacturing, Quality data as well as reporting are the various indicators of CQMP under the study of Quality management. Saraph et al (1985) interpreted the variable of Quality data and reporting, Process management, Product service as well as design attributes of (CQMP). Anderson et al (1995) only used process management is a significant determinant of CQMP. Flynn (1995) interpreted process flow management, product design, as well as statistical process control. Powell (1995) studied process flow, flexible manufacturing, Zero defect mentality, benchmarking as well as measurement in order to clarify the concept of CQMP in more precise manner. Aihere et al (1996) evaluated statistical control process, internal quality information, Design quality management and Benchmarking in a different physical context of organizational in order to find out how Quality management practices works in more dynamic situation.

(Laohavichienet, et.al., 2011) conducted a research on process management, Statistical control process, design quality management (Various indicators of CQMP) for the better interpretation of Quality management practices. 
Flynn (1995a) interpreted the statistical process control in order to provide explanation for CQMP. The purpose of statistical process control was to investigate the skills of employees. Ifemployee's skills are not enough to compete with uncertain situation in institution then proper training and development statistical process control can be improved (Aihere et al, 1996; Laohavichien et al.2011).

Aihere et al (1996) examined designed quality management techniques for the evaluation of quality management practices. The purpose of (DQM) was to increase collaboration among group members which leads to the better team collaboration. This action of employees will foster organizational process to develop quality products.

H1; Transactional Leadership have positive and significant relation with infrastructure quality management practices.

H2; Transformational Leadership have positive and significant relation with infrastructure quality management practices.

H3. Infrastucture QM practices have positive impact on core QM practices among Pakistan SME's.

H4. Core QM practices improve the quality performance of Pakistan SME's sector.

\section{RESEARCH METHODOLOGY}

Current research studv used the aualitv management model used bv Flvnn etal

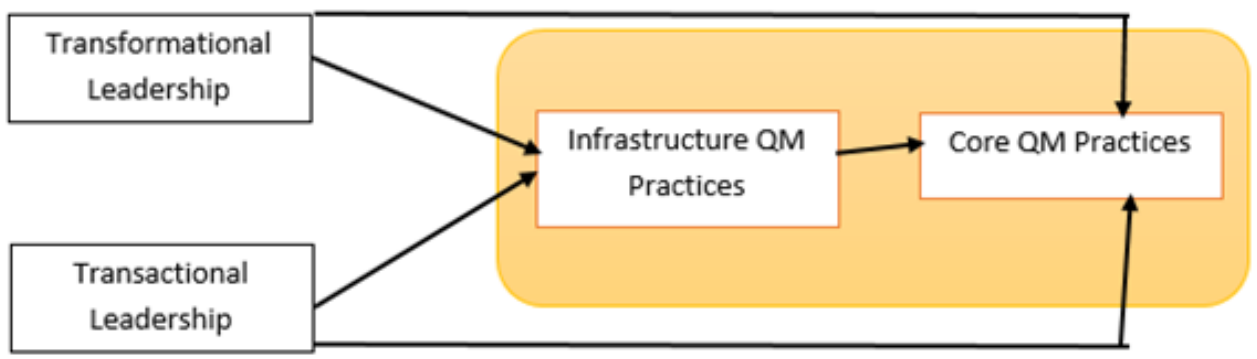

Figure 3.1. Conceptual Framework.

(1995) and Laohavichien et al (2011a; 2009b) in order to find out the impact of leadership styles in Pakistan QM model consist of eight infrastructure and core quality management practices.

According to Heberlein and Baumgartner (1978) as well as Dillman (1978) there may be problem if question show lower response. In order to tackle with such problem items were deleted on the basis of Spearman Brown prophecy formula. According to this formula each one dimension must have at least three items. Confirmatory Factor Analysis (CFA) was also performed in order to check item relevant loading of each constrict.

Page $\mid 51$ 
Both style of leadership (Transformational and Transactional) as well as core quality management practices were measured on seven point Likert scale ranging from One (1) strongly disagree to seven (7) strongly area, while infrastructure quality management practices was measured on Likert scale showing 1 for (significantly decreased) and 7 for (significantly increased) for the Current study unit of analysis was plant, as at this level quality management practices are strongly applied. About leaders characteristics respondents were quality department managers, director and supervisors. They were requested to rate their leaders on the basis of (Podsakffectall, 1990 \& 1993) construct control variable for the current study were factory size, industry type and QMP duration

- Validity of content in English version was tested by 8 PHD faculty with expertise in quality management practices 7 PHD scholar in leadership studies and 15 evening MBA executive student who have at least two years managerial experience.

- For the current study back translation method was also applied in order to find solution to linguistic problems.

- Current research study used personally administrated questionnaire. Advantage of such technique is to obtain right information from original source. For this purpose, help from research group (MS students) was also used population of the study was all the SME's in KPK Islamabad region and proper response. In total 500 questionnaires were distributed among selected manufacturing sector. We receive 486 filled questionnaires but after removing those which consist of missing valves. Finally, 360useable questionnaires for final analysis were available. For analysis we used confirmatory factor Analysis (CFA) for item leading and structural equation molding (SEM) through AMOS.

\section{Data Analysis}

Profile of respondent is shown in table (I), which clearly show the respective share of various manufacturing sector of Pakistan SMES table also throw light on the tenure since insemination of QM Practices and level of employees.

Table (4.1) show different manufacturing sector SME's in northern region of Pakistan in KPK province. Total of 15 different types of SME's manufacturing sector in northern area of Pakistan and KPK province. Out of these 15 different manufacturing sector SME's the largest participation for current research is of wood manufacturing product (47) which is $(13.05 \%)$ of total sample size. Second highest response rate was of leather products $(50)(13.88 \%)$ of total sample size followed by carpet and its different types (40) (11.11\%). Tobacco product manufacturing SME's response rate was (37) which is $(10.27 \%)$ of total sample. Chemicals and Fertilizer sector as well as stone, Clay and glass product response rate was 30 each that was $(08.33 \%)$. The lowest response rate was from cosmetic and fabricated material that consist of 5 respondent each i.e. (01.33\%) of total sample size. Cosmetic SME,s consist of packaging for different deodorants as well as their chemical synthetic final material at distract Swat, while fabricated material consist of different product for the final product i.e. cloths and other embroidery.

Table 4.1: Number of industries types, employees and QMP durations 
IBT Journal of Business Studies (IBT-JBS) Volume 15 Issue 2 December 2019

\begin{tabular}{|c|c|c|c|c|c|c|c|c|}
\hline \multirow{2}{*}{ S.N } & \multirow{2}{*}{ Industry } & \multirow{2}{*}{ Freq } & \multicolumn{3}{|c|}{ No of employees } & \multicolumn{3}{|c|}{ Duration of QMP } \\
\hline & & & $10-20$ & $21-50$ & $51-100$ & $<<$ & $1-3$ & $>3$ \\
\hline 1. & Tobacco prod & 37 & 12 & 20 & 05 & 06 & 30 & 01 \\
\hline 2. & Textile mills product & 29 & 5 & 14 & 10 & 18 & 06 & 05 \\
\hline 3. & Wood product & 47 & 11 & 30 & 06 & 32 & 13 & 02 \\
\hline 4. & $\begin{array}{l}\text { Paper \& allied } \\
\text { product }\end{array}$ & 15 & 5 & 14 & 01 & 10 & 05 & 00 \\
\hline 5. & Electric Equipment & 17 & 5 & 11 & 01 & 14 & 02 & 01 \\
\hline 6. & $\begin{array}{l}\text { Rubber \& plastic } \\
\text { prod }\end{array}$ & 10 & 05 & 05 & 00 & 08 & 02 & 00 \\
\hline 7. & $\begin{array}{l}\text { Stone, clay, glass } \\
\text { prod }\end{array}$ & 30 & 18 & 10 & 02 & 22 & 06 & 02 \\
\hline 8. & Chemicals, fertilizer & 30 & 02 & 18 & 10 & 05 & 22 & 03 \\
\hline 9. & $\begin{array}{l}\text { Lather \& shoes } \\
\text { industries }\end{array}$ & 50 & 10 & 42 & 08 & 18 & 30 & 02 \\
\hline 10. & Furniture \& fixture & 20 & 10 & 08 & 02 & 12 & 08 & 00 \\
\hline 11. & Carpet etc & 40 & 05 & 25 & 10 & 02 & 21 & 17 \\
\hline 12. & $\begin{array}{l}\text { Primary metal } \\
\text { industries }\end{array}$ & 12 & 04 & 07 & 01 & 01 & 10 & 01 \\
\hline 13. & Cosmetic products & 05 & 03 & 02 & 00 & 01 & 04 & 00 \\
\hline 14. & Fabricated material & 05 & 00 & 02 & 03 & 01 & 04 & 00 \\
\hline 15. & Miscellaneous & 13 & 02 & 10 & 01 & 02 & 09 & 02 \\
\hline
\end{tabular}

Response rate of rubber and miscellaneous plastic products was $10(02.77 \%)$, for paper and allied products was 15 respondent that is $(04.16 \%)$ of total sample size. The information about number of employees response show that only one SME's sector (fabricated material) indicate that most enterprises have employees rate higher than 51. While remaining almost all SME's sector shows that average enterprises have employees rate between 10 to 20 persons. While from wood product, textile mills and tobacco as well as lather industries have employees in the range of 21 up to 50. Respondent rate against the question of applying quality management practices (QMP) duration show that Carpet industry and Textile product SME's have the longest period of adopting (QMP's) i.e. more than 3 years. Response of stone, clay and glass material show that they were using QMP's since last on year. There was mix response regarding using of any quality management practices i.e. ISO series or other quality practices.

Table 4.2. Factor loadings of 8 factors model of transformational and transectional leadership (model 0)

Estimates

\begin{tabular}{|l|l|l|}
\hline APM1 & Appropriate Model & 0.65 \\
\hline APM2 & Appropriate Model & 0.67 \\
\hline APM3 & Appropriate Model & 0.71 \\
\hline AV1 & Articulating vision & 0.65 \\
\hline AV2 & Articulating vision & 0.54 \\
\hline
\end{tabular}


IBT Journal of Business Studies (IBT-JBS) Volume 15 Issue 2 December 2019

\begin{tabular}{|l|l|l|}
\hline AV3 & Articulating vision & 0.59 \\
\hline IS1 & Intellectual stimulation & 0.54 \\
\hline IS2 & Intellectual stimulation & 0.59 \\
\hline IS3 & Intellectual stimulation & 0.66 \\
\hline ISP1 & Inspirational Motivation & 0.63 \\
\hline ISP2 & Inspirational Motivation & 0.79 \\
\hline ISP3 & Inspirational Motivation & 0.89 \\
\hline HP1 & High Performance & 0.66 \\
\hline HP2 & High Performance & 0.77 \\
\hline HP3 & High Performance & 0.71 \\
\hline GG1 & Group Goals & 0.55 \\
\hline GG2 & Group Goals & 0.51 \\
\hline GG3 & Group Goals & 0.71 \\
\hline GG4 & Group Goals & 0.85 \\
\hline CR1 & Contingent Reward & 0.66 \\
\hline CR2 & Contingent Reward & 0.71 \\
\hline CR3 & Contingent Reward & 0.54 \\
\hline CP1 & Contingent Punishment & 0.67 \\
\hline CP2 & Contingent Punishment & 0.78 \\
\hline CP3 & Contingent Punishment & 0.71 \\
\hline
\end{tabular}

Figure 4.1.: $\quad$ Eight factor model of both leadership styles (transformational \& transactional)

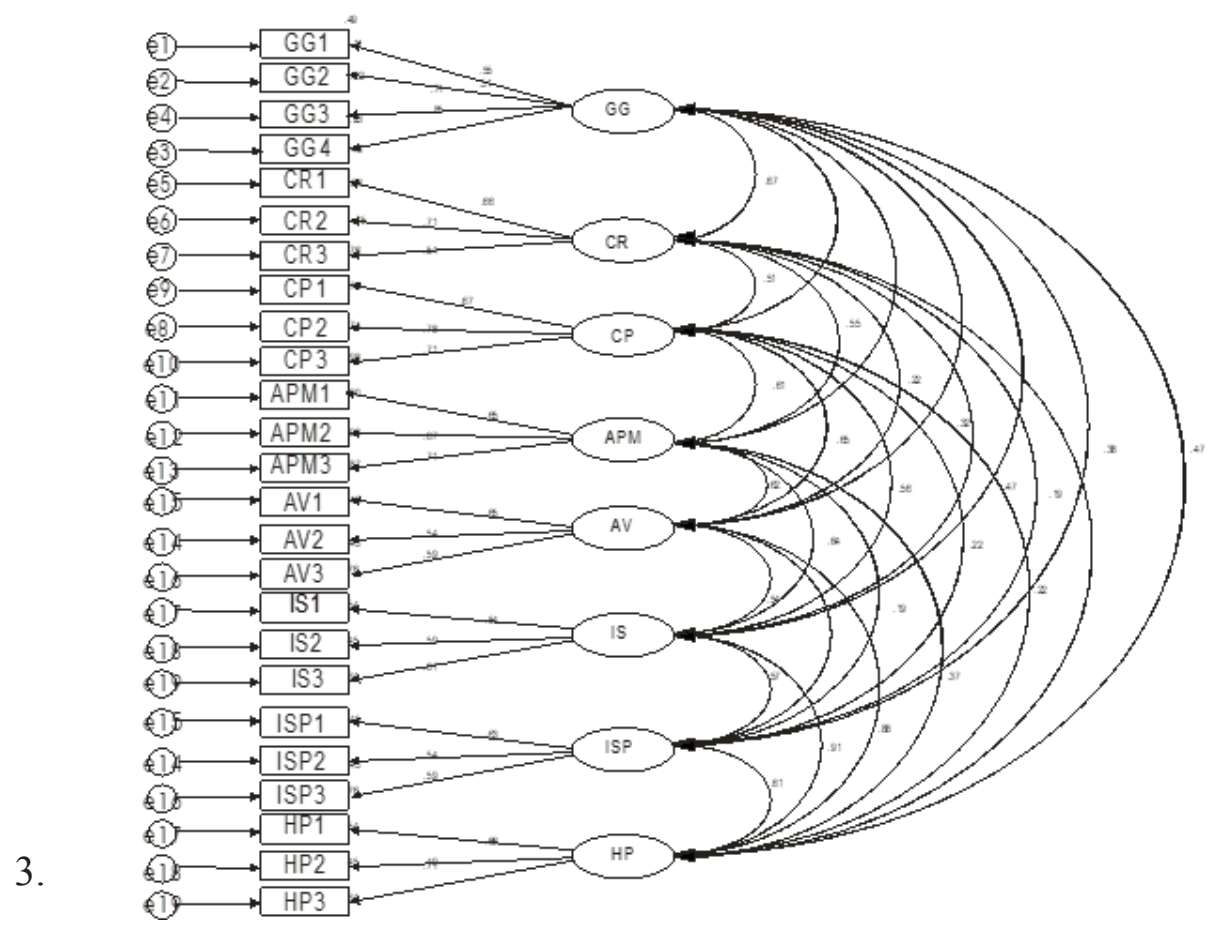




\section{Measurement of convergent $\&$ discriminate validities for 8 factor model of leadership}

In Order to examine convergent and discriminate validities Fornell \& Larcker's (1981) and Javed et al. (2011) method was adopted for the measurement of eight factor model of leadership. The $\rho \mathrm{VC}$ indexes for $\mathrm{CR}, \mathrm{CP}$ were $(51 \%$ and $49 \%)$ respectively (Transactional Leadership Style). While $\rho$ VC index for measurement of AV, AM, IC and G.G were (56\%), (44\%) (47\%) and (51\%) respectively (transformational leadership). High performance and intellectual stimulation PVC index were $(60 \%)$ and $(43 \%)$ (Transformational Leadership). JoreskogRoh value of construct was CR (.77), CP (.81) CP (.81), AV (.72), and AM (.84), IC (.76), GG (.77), HP (.83), I.S (.80) respectively (see table 4.3).

Table 4.3: Average variance extracted and shared and shared variances among eight factor model of leadership

\begin{tabular}{|l|l|l|l|l|l|l|l|l|l|}
\hline & CR & CP & AV & AM & IC & GG & H.P & I.S & CNR \\
\hline CR & 0.51 & & & & & & & & 0.77 \\
\hline CP & 0.22 & 0.49 & & & & & & & 0.81 \\
\hline AV & 0.12 & 0.22 & 0.56 & & & & & & 0.72 \\
\hline AM & 0.03 & 0.26 & 0.16 & 0.44 & & & & & 0.84 \\
\hline IC & 0.00 & 0.81 & 0.33 & 0.08 & 0.47 & & & & 0.76 \\
\hline GG & 0.11 & 0.84 & 0.35 & 0.09 & 0.10 & 0.51 & & & 0.77 \\
\hline HP & 0.91 & 0.22 & 0.36 & 0.47 & 0.42 & 0.09 & 0.60 & & 0.83 \\
\hline I.S & 0.06 & 0.15 & 0.09 & 0.19 & 0.21 & 0.19 & 0.22 & 0.4 & 0.80 \\
\hline
\end{tabular}

The variances shared between different factors of transformational and transactional leadership 8 factor model were high than exerted variances. However factors contingent punishment (HP) \& contingent reward (CR) show high correlation $(0.810)$ and $(0.91)$ respectively. We than combined the highly correlated factor and ran new CFA on 6 factor model of leadership (transactional and transformational leadership model adapted from Podaskoff (1990). Model fit indices shows that (x2/ df) $=2.22, \mathrm{CFI}=.90, \mathrm{TLI}=.88, \mathrm{RMSEA}=.12$ (see table 4.4).

Table 4.4: Fit indices result for both 8 factor $\& 6$ factor leadership model (combined)

\begin{tabular}{|l|l|l|l|l|l|l|l|}
\hline & X2/df & CFI & GFI & AGFI & TLI & NFI & RMSEA \\
\hline Model 1 (8 Factor's) & 1.85 & .924 & .912 & 1.00 & .932 & .885 & .073 \\
\hline Model 2 (4 Factor's) & 2.22 & .903 & .894 & .953 & .883 & .831 & .120 \\
\hline
\end{tabular}

The result show that 8 factor model of leadership (transformational and transactional) is good fit on the best fit model for further analysis. The results indicate that 8 factor model. So we will use 8 factor model (6 factor transformational leadership and 2 factor transactional leadership) for further analysis.

Table 4.5: Comparison of leadership combine models

\begin{tabular}{|l|l|l|l|}
\hline & Chair square & Df & P \\
\hline Model 1,8 (dimensions) & 852.33 & 440 & $0.00 \%$ \\
\hline
\end{tabular}


IBT Journal of Business Studies (IBT-JBS) Volume 15 Issue 2 December 2019

\begin{tabular}{|l|l|l|l|}
\hline Model 2, 4 (dimensions) & 891.41 & 451 & $0.00 \%$ \\
\hline & 39.08 & 11 & $0.08 \%$ \\
\hline
\end{tabular}

Table 4.6. Inter correlation among the variables.

\begin{tabular}{|l|l|l|l|l|l|l|l|l|}
\hline & (CP) & (AV) & (AM) & (GG) & (HRM) & (MS) & (PM) & (DQM) \\
\hline $\begin{array}{l}\text { Contingent } \\
\text { Punishment (CP) }\end{array}$ & 1.00 & & & & & & & \\
\hline $\begin{array}{l}\text { Articulating } \\
\text { Vision(AV) }\end{array}$ & 0.601 & 1.00 & & & & & & \\
\hline $\begin{array}{l}\text { Appropriate } \\
\text { Model(AM) }\end{array}$ & 0.588 & 0.478 & 1.00 & & & & & \\
\hline Group Goal(GG) & 0.712 & 0.622 & 0.588 & 1.00 & & & & \\
\hline $\begin{array}{l}\text { Human } \\
\text { Resource(HRM) }\end{array}$ & 0.512 & 0.432 & 0.398 & 0.612 & 1.00 & & & \\
\hline $\begin{array}{l}\text { Management } \\
\text { Support(MS) }\end{array}$ & 0.722 & 0.566 & 0.498 & 0.566 & 0.802 & 1.00 & & \\
\hline $\begin{array}{l}\text { Process } \\
\text { Management(PM) }\end{array}$ & 0.515 & 0.431 & 0.423 & 0.621 & 0.543 & 0.643 & 1.00 & \\
\hline $\begin{array}{l}\text { Design Quality } \\
\text { Management DQM }\end{array}$ & 0.675 & 0.453 & 0.633 & 0.715 & 0.516 & 0.323 & 0.456 & 1.00 \\
\hline
\end{tabular}

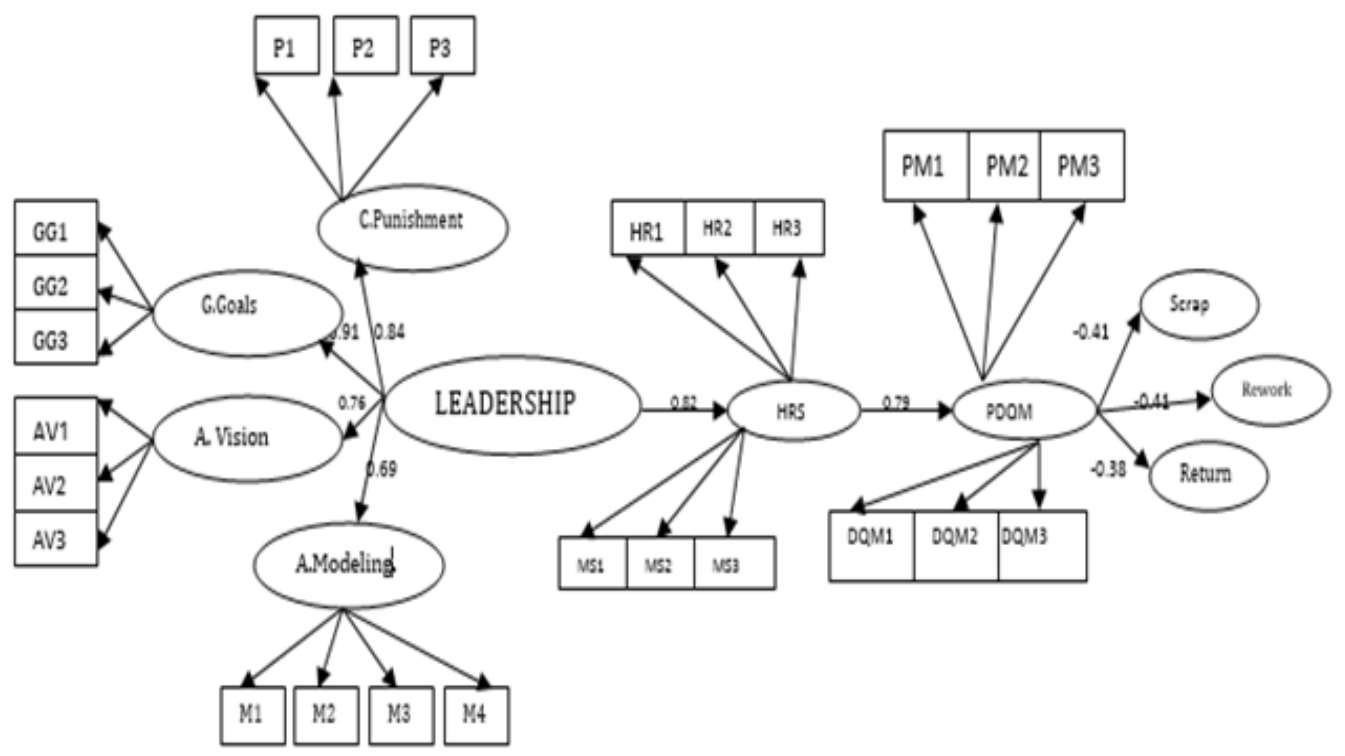

Figure 2. Final SE Model Findings.

Direct path relation was checked and result indicate worse relationship when leadership affect is directly checked with core QM practices. Finally only two Infrastructure Quality Management Practices (HRM and Management Support was retained). While from core QM practices (Process Management "PM" and Design Quality Management "DQM") were retained in the final model. Infrastructure 
quality management practices was renamed as Human Resource Support (HRS) and Core Quality Management Practices (CQMP) was titled Design and Process Control (DPC). While in study of (Laohavichien et al.,2011) only one factor (HRM) from infrastructure Quality Management (IQM) was retained as a result IQM was renamed as HRM. And from three attributes of core QM Practices only process control was retained because of Model fit value. Hence it was also renamed as Process Control instead of core QM practices (Laohavichien et al.,2011; Saif, 2015).

Finally from result it is shown that hypothesis was clearly supported as during SEM analysis most of the factor from original construct was removed. From leadership behavior only three factor were retained, because during CFA only 4 factors from leadership (Contingent Punishment from transactional as well as Group Goal Behavior, Articulating Vision, Appropriate Model were retained from transformational). In contrast from infrastructure Quality Management Practices (HRM and Management Support) and core QM practices (PM \& DQM) were retained. The overall model fit values for four factor model of Leadership is (X2/ $\mathrm{df}=2.22$; $\mathrm{CFI}=0.93 ; \mathrm{GFI}=.893 ; \mathrm{TLI}=.883 ; \mathrm{RMSEA}=.120$ ). While model fit values of CFA for combine CQMP and IQP to asses quality Management Practices is (X2/ $\mathrm{df}=1.18 ; \mathrm{CFI}=0.96 ; \mathrm{GFI}=.993 ; \mathrm{TLI}=.883 ; \mathrm{RMSEA}=.144)$. In order to assess the Discriminant validity the value of (X2) for basic and baseline model was compared with (X2) of the correlation among the variables. Results from table (4.6) indicate that values of all variables are significant at one degree of freedom (Laohavichien et al, 2011).

The values of adjusted R2 in the final model for scrape and returns are (-0.312 and -0.253$)$ respectively. While adjusted R2 value for reward was (-0.181). Similar results were found by (Laohavichien et al, 2011) in comparing the impact of applying QM practices in Thailand and USA. These findings up to same extent support the concept that in order to get maximum benefits from core QM practices, infrastructure QM practices must be applied in the first stage. On the other side leadership style also shows influence on core QM practices. And the values from (Designed and Process Control) also evident strong effect on Scrape, Rework and Returns (see figure 2). The values for Return and Rework of dependent variable shows (-vie) but significant findings, while Scrap having insignificant result. It indicate that if QM practices may not be applied in its true sense than the final product would be return by customer/ dealer and rework process will be initiated to overcome customers/dealer complaints. The findings of (Laohavichien et al, 2011 ) indicate that (scrap, rework and return) all are significant associated to QM practices. While (Saif, 2015) found same results. It shows that with application of QM practices return and rework will significantly decreased. Finally results related to hypothesis indicate that almost all the hypothesis are partially accepted as transformational and transactional leadership impact on IQMP was assessed through joint effort of leadership attributes. The relationship between infrastructure QMP (HRM and Management Support) and quality performance was mediated by Core QM practices (Process Management and Design Quality management). 


\section{CONCLUSION AND RECOMMENDATIONS}

Current research study tries to use the concept developed by (Flynn,1995) and validated by (Laohavichien et al, 2011) in Thailand and USA SME's manufacturing sector. For this purpose SEM analysis technique was used. Although transformational and transactional leadership are two diverse forces, but in the current study during second order factor it was loaded on single attribute. As only three dimension of transformational (Articulating Vision, Group Goal \& Appropriate Modelling), and one factor of transactional leadership (Contingent Punishment) were found strongly loaded on single factor. Hence finding of the study are contributing in nature, as overall leadership play a pivotal role for paving ways to implement QM practices. Results of the study strongly support that leadership among Pakistani SME's focus on group goal achievement. At the same time these leaders provide vision to their employees and also guideline during poor performance. Articulating vision among employees and group goal behavior can be flourish through modeling appropriate behavior. This suggest that by providing appropriate behavior modeling, employee's attitude could be mold in the desired direction. Findings from the former study support mediation impact of core QM practices. While results from (Loahavichien et al 2011) particularly support the mediational role of QM practices. Our results also support previous model. Hence it is evident that both types of QM practices are equally important for success of Pakistan SME's manufacturing sector.

During second order factor analysis many of the items were deleted and only two factor from core QM practices namely (HRM and management support) were retained. It shows that proper training and development skills are important factors for high quality product and services environment. At the same time support from management for organizing training and innovative work behavior are also become crucial part for quality oriented environment. Results of the current study are also in line with findings of (Zu et al , 2008; Saif., 2015).

In the current study Contingent punishment attribute of Transformational leadership is retained during the analysis. It support the findings of earlier researchers (Saif, 2015; Laohavichien et al, 2011), while (Laohavichien et al, 2009) found that both characteristics of transactional leadership are equally important during implementation stage of QM policy. The findings are also contradict to the (Deming, 1994) model of leadership, which emphasize that reward and punishment based philosophy is not appropriate for QM practices. This also support earlier theorist about leadership styles, the transportation and transactional are not actually exclusive behavior. It is possible that most of the leader exhibit both styles at a time according to the situation. Results also favor that in Pakistan contingent punishment attribute strongly emphasize employees to perform better otherwise because of local problems (Energy Crisis, lack of good governance, nepotism, and other social evil) can put question mark about their position in organization.

Findings also emphasize to investigate the phoneme is more detail for the betterment of Pakistan SME's manufacturing sector. There are some limitation of the current study. 
First: National culture is an important part of employing QM practices in any organization. As national policy about implementation of QM practices can further improve the standards. In future the researchers may investigate the role of organizational as well as national culture to validate the current model.

Second: Response were obtained from single person and single organization. It can create problems of common method variances (Ketokivi \& Schroeder, 2004). In future response from multiple organization in the same sector may be investigated to get in depth information's.

Third; Various factors such as Organization Citizenship Behavior, employee's commitment, government policies, organization cynicism must be studied as possible mediator or moderator role. It will give us much more detail information about the philosophy.

Fourth; Current study is conducted in manufacturing sector only. In future if the same concept is applied in SME's services sector across the provinces of Pakistan, it will be also beneficial to understand the reaction of two different sectors to the underline concept.

Fifth; If the SME's sector performance are measured on SARRC countries or (Group of two countries i.e. one from developing nations like Pakistan and another one from industrially developed countries like USA,UK etc ) will further enhanced the researcher understanding to find out the loop whole and hurdles in the adaptation of the current concept.

\section{REFERENCES}

Ahire, S.L. (1996), "TQM age versus quality: an empirical investigation", Production \& Inventory Management Journal, 37 (1), pp. 18-23.

Anderson, J.C., Rungtusanatham, M., Schroeder, R.G. and Devaraj, S. (1995), “A path analysis model of theory of quality management underlying the Deming management method: preliminary empirical findings", Decision Sciences, 26(5), pp. 637-58.

Bass, B.M. and Avolio, B.J. (1997), Full Range Leadership Development: Manual for the Multifactor Leadership Questionnaire, Mind Garden, Palo Alto, CA.

Bass, B.M. (1985), Leadership and Performance Beyond Expectations, The Free Press, New York, NY.

Bass, B.M. (1985), Leadership and Performance Beyond Expectations, The Free Press, New York, NY.

Burns, J.M. (1978), Leadership, Harper \& Row, New York, NY.

Curkovic, S., Vickery, S. and Droge, C. (2000), "Quality-related action programs: Their impact on Quality Performance and Firm Performance", Decision Sciences, 31(4), pp. 885-905.

Dansereau, F. Jr, Graen, G. and Haga, W.J. (1975), “A vertical dyad linkage approach to leadership within formal organizations: a longitudinal investigation of the role making process", Organizational Behavior and Human Performance, 13(1), pp. 46-78.

Page 59 
Dean, J. and Bowen, D. (1994), "Management theory and total quality: improving research and practice through theory development", Academy of Management Review, 19(3), pp. 392-418.

Deming, W.E. (1986), Out of the Crisis, MIT Press, Cambridge, MA.

Dillman, D.A. (1978), Mail and Telephone Surveys, Wiley, New York, NY.

Flynn, B.B., Schroeder, R.G. and Sakakibara, S. (1995).“The Impact of Quality Management Practices on Performance and Competitive Advantage", Decision Sciences, 26(5), pp. 659-91. Retrieved from: www.piqc.com.pk/case studies/ services

Heberlein, T.A. and Baumgartner, R. (1978), "Factors Affecting Response Rates to Mailed Questionnaires: A Quantitative Analysis of the Published Literature", American Sociological Review, pp. 447-62.

House, R.J. (1971), “A Path-Goal Theory of Leader Effectiveness”, Administrative Science Quarterly, pp. 321-39.

Jain, B.A. and Tabak, F. (2002), "Organizational quality management in emerging economies", Quality Management Journal, 9(2), pp. 10-24.

Ketokivi, M.A. and Schroeder, R.G. (2004), "Perceptual Measures of Performance: Fact or Fiction?", Journal of Operations Management, 22, pp. 247-62.

Laohavichien,T . Lawrence D, F. and R,Stephen ,C. (2011), "Leadership and Quality and Quality management Practices in Thailand. International Journal of Production and Operation Management, 31(10), 1048-1070

Laohavichien,T . Lawrence D, F. and R,Stephen ,C. (2009), "The effect of Transformational and transnational leadership on Quality Improvement. Quality Management Journal, 16(2), 7-24.

Omar,H,O. (2017); Transformational Leadership in Quality Management. Graduate Research Thesis. The University of Montana. Missoula, MT

Podsakoff, P.M., MacKenzie, S.B. and Bommer, W.H. (1996), "Transformational leader behaviors and substitutes for leadership as determinants of employee satisfaction, commitment, trust, and organizational citizenship behaviors", Journal of Management, 22(2), pp. 259-98.

Podsakoff, P.M., MacKenzie, S.B. and Fetter, R. (1993a), "Substitutes for leadership and the management of professionals", Leadership Quarterly, 4(1), pp. 1-44.

Podsakoff, P.M., MacKenzie, S.B., Moorman, R.H. and Fetter, R. (1990), "Transformational leader behaviors and their effects on followers' trust in leader, satisfaction, and organizational citizenship behaviors", Leadership Quarterly, 1(2), pp. 107-42.

Podsakoff, P.M., Niehoff, B.P., MacKenzie, S.B. and Williams, M.L. (1993b), "Do substitutes for leadership really substitute for leadership? An empirical examination of Kerr and Jermier's situational leadership model", Organizational Behavior and Human Decision Processes, 5(4), pp. 1-44.

Powell, T.C. (1995), "Total quality management as competitive advantage: a review and empirical study", Strategic Management Journal, 16(1), pp. 15-37.

Ribera, J., Samson, D. and Westbrook, R. (1997), "An International Study of Quality Improvement Approach and Firm Performance", International Journal of Operations \& Production Management, 9(17), pp. 842-73.

Rahman, S. and Bullock, P. (2002), "Relationships between soft TQM, hard TQM, and organizational Performance", Working Paper ITS-WP-02-10, available at: www.its.usyd.edu.au. 
Rehan.H.M., Adeel.M., \& Khan.I. (2016); The Leadership Styles and Quality Management: A Literature Review. Industrial Engineering Letters. IISTE, 6(5), 2016

Saif,N.(2015); Impact of Leadership styles on Quality Management Practices; The Mediating Role of Organization culture and Organization Citizenship Behavior. PhD Dissertation. Gomal University, Dera Islmail khan, Khyber PakhtoonKhwa, Pakistan.

Saraph, J.V., Benson, P.G. and Schroeder, R.G. (1989), "An instrument for measuring the critical factors of quality management", Decision Sciences, Vol. 20, pp. 810-29.

Sousa, R. and Voss, C.A. (2001), "Quality management: universal or context dependent?", Production and Operations Management, Vol. 10 No. 4, pp. 383404.

Sousa, R. and Voss, C.A. (2002), "Quality management re-visited: a reflective review and agenda for future research", Journal of Operations Management, 20(1), pp. 1-19.

Steinbacher, H.R. and Steinbacher, N.L. (1993), TPM for America: What it is and Why You Need It, Productivity Press, Portland, OR.

Waldman, D. (1994), "The contributions of total quality management to a theory of work performance", Academy of Management Review, Vol. 19 No. 3, pp. 510-36.

Waldman, D., Lituchyu, T., Gopalakrishnan, M., Laframboise, K., Galperin, B. and Kaltsounakis, Z. (1998), "A qualitative analysis of leadership and quality improvement”, Leadership Quarterly, 9(2), pp. 177-201 